\title{
Ferhengnâme-yi Sa'dî Tercümesi'nde Kullanılan Bazı Deyimler ve Deyimlerin Farsça Karşılıkları
}

\section{Some Idioms Used in Ferhengname-yi Sadi Tercumesi and Their Persian Equivalents}

\author{
Funda $\operatorname{San}^{1}$ (1)
}

${ }^{1}$ Yıldız Teknik Üniversitesi, Fen-Edebiyat Fakültesi, Türk Dili ve Edebiyatı Bölümü, İstanbul, Türkiye

ORCID: F.Ş. 0000-0002-7357-4668

Sorumlu yazar/Corresponding author: Funda Şan,

Yıldız Teknik Üniversitesi, Fen-Edebiyat Fakültesi, Türk Dili ve Edebiyatı Bölümü, İstanbul, Türkiye

E-mail: sanfunda@hotmail.com

Başvuru/Submitted: 22.05.2020

Revizyon Talebi/Revision Requested: 03.12.2020 Son Revizyon/Last Revision Received: 13.12 .2020 Kabul/Accepted: 16.12 .2020

\section{Atuf/Citation:}

San, F. (2021). Ferhengnâme-yi Sa'dî

Tercümesi'nde kullanılan bazı deyimler ve deyimlerin Farsça karşılıkları. TUDED, 61(1), 283-302.

https://doi.org/10.26650/TUDED2020-0040

\section{ÖZET}

Ferhengnâme-yi Sa'dî Tercümesi, Hoca Mes'ud bin Ahmed'in 1354/1355 (H.755) yılında Sa'dî'nin 1257 yılında yazdığ 1 Bostan adlı Farsça eserinden Türkçeye tercüme ettiği didaktik bir eserdir. Bostan, ahlak, eğitim, evlilik, devlet yönetimi gibi pek çok konu hakkında nasihatlerin bulunduğu hem kendi döneminde hem de sonraki dönemlerde üzerine müntehâblar (seçkiler), muhtasarlar ve nazireler yazılan Fars edebiyatı için mühim bir mesnevidir. Hoca Mes'ud tarafından 14. yy'da yazılan eser ise 4044 beyitlik Bostan'ın yaklaşı bin beyitlik tercümesidir. Hoca Mes'ud eserin girişinde bu tercüme sırasında mümkün olduğunca yabancı kelimelere yer vermediğini belirtmiştir. Eser hakikaten de Eski Anadolu Türkçesi döneminin Türkçe söz varlığının zenginliğini ortaya koymaktadır. Ancak Hoca Mes'ud her ne kadar yabancı kelimelere yer vermediğini belirtmiș olsa da aynı zamanda mana ve biçim bakımından mümkün olduğunca ana metne sadık kalmaya çalıştı̆̆ını da ifade etmiştir. $\mathrm{Bu}$ sebeple eser Türkçe yazılmaya çalışılmış olsa da Farsçadan tercüme bir eser olması dolayısıyla bazı Farsça yapı ve kalıpların izlerini taşımaktadır. Bu yapılardan biri de eserde anlatımı güçlendirmek için kullanılan deyimlerdir. Çalışmada Hoca Mes'ud'un eserindeki deyimler tespit edilmiş ve bunların Farsça karşılıklarına yer verilerek aralarındaki benzerlik ortaya konmaya çalışılmıştır.

Anahtar Kelimeler: Ferhengnâme-yi Sa'dî Tercümesi, Hoca Mes’ud, Bostan, Eski Anadolu Türkçesi, deyimler

\section{ABSTRACT}

Ferhengnâme-yi Sa'dî Tercümesi is a didactic text translated into Turkish by Hodja Mes'ud bin Ahmed in 1354/1355 (H.755) from Sa'dî's Persian text Bustan written in 1257. Bustan, on which selective and parallel texts have been written both in its period and later on, is an important mesnavi in Persian literature that gives advice on many topics such as morality, education, marriage, and state administration. While Bustan is composed of 4044 couplets, Ferhengnâme-yi Sa'dî Tercümesi has just approximately one thousand couplets. Hodja Mes'ud remarks in the introductory part of the work that he did not use any foreign words in this translation. The text indeed manifests the richness of Turkish vocabulary in the Old Anatolian Turkish period. However, although Hodja Mes'ud claims that he avoided using foreign vocabulary, he also mentions to have stayed with the original script in terms of meaning and structure and the work has traces of some Persian structures and patterns, as it is a translation from Persian. One of these structures is the use of idioms to strengthen expression in the work. In this study, the idioms in the text of Hodja Mes'ud are identidied and similarities between these idioms and their Persian equivalents are shown.

Keywords: Ferhengnâme-yi Sa'dî Tercümesi, Hodja Mes'ud, Bustan, Old Anatolian Turkish, Idioms 


\section{EXTENDED ABSTRACT}

Ferhengnâme-yi Sa'dî Tercümesi (The Translation of Ferhengname-yi Sadi) is a didactic mesnevi written in the $14^{\text {th }}$ century in Old Anatolian Turkish. The writer, Hodja Mes'ud bin Ahmad acknowledges that he translated his work in 1354/1355 (H.755) from the Persian version called Bustan by Sadi dated 1257. Although Bustan has 4044 couplets, Ferhengnâme-yi Sa'dî Tercümesi has just around one thousand couplets.

In the introduction, Hodja Mes'ud implies that he did not use any foreign words in his translation work. The text actually portrays the richness of Turkish vocabulary in the Old Anatolian Turkish period. However, although Hodja Mes'ud claims that the work has been written in pure Turkish, he also tried to keep the original form and the structure. When we compare his translation and the original text, we can easily say that they are written in a very similar form. Ferhengnâme-yi Sa'dî Tercümesi was written in the same meter of mutekarib (feûlun feûlun feûlun feûl) just as Bustan.

Ferhengnâme-yi Sa'dî Tercümesi and Bustan also have similarities in terms of meaning. As Hodja Mes'ud mentions in his text, he tried to keep the meaning as he did for the form.

Hoca Mes'ud states that the book he intended to write was not original Bustan, but a concise work created with selected couplets from it. Fuad Koprulu and Kilisli Muallim Rifat also stated that they examined many of the shortened and selective Bustan and none of them were compatible with the work written by Hodja Mes'ud. Unfortunately, despite my long-term efforts, I also could not find a shortened Persian copy that overlaps with the work of Hodja Mes'ud.

Although I did not find the original of the work, when we compare the text with the original Bustan, we see that the meaning of the couplets in Persian and Turkish overlap. In other words, as Hoca Mes'ud said, the work had been translated in the same meter with Persian and without much change in the meaning. In the copy published by Kilisli Muallim Rifat, some couplets in Persian forms are also added as a footnote. Comparing the Persian and Turkish forms of these couplets, some couplets seem to be exactly the same. As Rifat did, I also compared some other coupletes in the two languages, and I found that the translation was made word for word from Persian to Turkish in some couplets. As an example, in Turkish, götürmez-mi-di yèl her șubḥ u şām/Süleymān serīrin 'alayhi's-salām (Kopenhagen: couplet 72) (Did wind not bring Suleiman's crown from place to place every day and every night); is translated from Persian text, ne ber bād reftì sehergāh u şām/serīr-i Süleymān 'aleyhi s-selām (Bustan: page 83/couplet 13)

As was Ferhengnâme-yi Sa'dî Tercümesi, many other works such as Hüsrev and Şirin, Mantıku't-Tayr, Leyla and Mecnun, Yusuf and Züleyha were translated from Persian into Turkish during the period when Turkish was the written language in Anatolia. As a result of this, many Persian structures, phrases and words have been used widely in Turkish. Undoubtedly, one of these examples of structures that have been translated from Persian to Turkish is idioms. 
Many idioms that are still in use in contemporary Turkish also exist in Persian. The question of whether these idioms were transmitted from Persian to Turkish through texts or from Turkish to Persian verbally is controversial. However, it can be said that some of the idioms used in Turkish based on written texts were translated into Turkish during these translation activities and gained widespread usage in Turkish. One could also say Hoca Mes'ud must have tried to use the idioms that were already used in Turkish at that time, to make the text more meaninful and at the same time to stay with the Persian script.

Ferhengnâme-yi Sa'dî Tercümesi contains many idioms that were written in the Old Anatolian Turkish era in the $14^{\text {th }}$ century and translated from Persian Bustan and have similar use in terms of its structure such as dilüy çek-: dilini tutmak, susmak vs. zabān dar kashīdan: to keep in one's tongue. Apart from these, there are some idioms used in the Turkish version which are not the same as in the Persian couplets. However, same idioms might be found in Persian. One of the methods of creating this kind of idiom is taking the nouns as they are and adding a Turkish verb in the same meaning with Persian ones such as cem ' kll-: bir araya getirmek, toplamak vs. jam 'kardan: to assemble, bring together, collect. Another type of idiom used in the text is where nouns and verbs were different but with the same meaning such as $e l$ $y u$-: kötü bir şeyden uzak durmak, onu yapmaktan vazgeçmek vs. dast shustan: to abandon.

As I explained above, because Hodja Mes'ud tried to keep the form and the meaning close to its Persian version, Ferhengnâme-yi Sa'dî Tercümesi has traces of some Persian structures and patterns. One of these structures is idioms used to strengthen expression in the work. In this study, the idioms in the text of Hodja Mes'ud were identified and the similarities to their Persian equivalents were pointed out. 


\section{GİRiş}

Her toplumun dili, yaşadığı ortamın, göçlerin, inançların, gelenek ve göreneklerin ışığında yüzyıllar içerisinde şekillenmekte ve dönüşmektedir. Bu maddi ve manevi değerlerdeki herhangi bir değişim, karşılaşma ya da aktarım, dilin dinamiklerini değiştirip onun yeniden şekillenmesini sağlamaktadır.

13. yüzyılda Türklerin Anadolu’ya geçişiyle beraber Anadolu' da yeni bir yazı dili gelişmeye başlamıştır. Eski Anadolu Türkçesi olarak adlandırılan bu dilin edebî dil olma sürecinde elbette ki Arapçanın ve özellikle de komşu dil Farsçanın etkisi yadsınamaz. 13. ve 15. yüzyıllar arasında dilin oluşum sürecinde Anadolu'nun hemen yanı başında Sa'dî, Nizâmî gibi usta şairlerin kaleminden çıkan Farsça eserlerin, Eski Anadolu Türkçesi eserlerinin oluşumunda iyi bir örnek teşkil ettiği söylenebilir. Nitekim Eski Anadolu Türkçesi döneminde yazılan pek çok eserin Farsçadan çeviri ya da adaptasyon yoluyla Türkçeye kazandırıldığı görülmektedir.

Farsçadan Türkçeye yapılan çeviri faaliyetleri sırasında pek çok kelime, ek ve gramer yapısının yanında deyim, atasözü gibi dile ait pek çok kullanımın da Türkçeye geçtiği söylenebilir. Eski Anadolu Türkçesi dönemi eserleri ve onların Farsça orijinalinden örnek alınan eserler incelendiğinde iki dil arasındaki deyim, atasözü ve kalıp ifadelerdeki benzerliğin hayli fazla olduğu görülmektedir. Bu ifadelerin bazıları kelime kelime çeviri yöntemi ile bazıları da mealen çeviri yöntemiyle yapılmıştır. Deyim, atasözü ve kalıp ifadelerin ilk olarak hangi dilden diğerine geçtiği ancak her iki dilin çok eski dönemlere ait metinleri ayrıntılı olarak incelenerek elde edilebilir. Bu sebeple şimdilik bu alışverişin her iki dil içinde de karşılıklı olduğunu söylemek daha doğru olacaktır.

Çeviri faaliyetleri sırasında her ne kadar Farsça eserler örnek alınsa da kelimelerin Türkçe karşılıklarını kullanmak bu dönemin yazar ve şairleri için mühim meselelerden biridir. Örneğin Türkçenin hemen her kesiminde Farsça çoban kelimesi kullanılırken Eski Anadolu Türkçesi dönemi eserlerinde çoban kelimesi yanında güden veya güdücü kelimelerine de rastlanmaktadır. Aynı durum deyim yapımında da dikkat çeker. Bu dönemde Türkçede "karşılamak" anlamı taşıyan istikbal etmek yerine karşılayu çıkmak deyiminin de kullanıldığı görülmektedir (Aksan, 2013: s.54). Farsça dişında Avrupa dillerinden Türkçeye giren pek çok deyimin de geçmişte ve günümüzde benzer yolla Türkçeye kazandırılmış olduğu söylenebilir. Örneğin, MÖ. 4. yüzyılda yaşamış Siraküza kralı Dionysios'un krallığın rahat olduğunu savunan Demokles'e, bu işin ne kadar tehlikeli olduğunu anlatmak üzere, yemek esnasında başının üzerine koydurduğu at kılına bağl1 kılıç için kullanılan Demokles ’in kılıcı deyimi, birçok dilde olduğu gibi Türkçede de önemli mevkilere yönelik tehlikeli durumları anlatmak için kullanılan deyimlerden biridir (Aksan, 2002: 97-98). Özellikle İkinci Dünya Savaşı'ndan sonra İngilizcenin tüm dünyada yaygınlaşmasıyla birlikte İngilizce deyimler de diğer dillerde olduğu gibi Türkçede de etkisini göstermeye başlamıştır: kemerleri sıkmak "to tighten the belts", formunda olmak "to be in form", beyin yıkamak "brain washing"... (Aksan, 2002: 110-111). Yukarıda da belirttiğimiz gibi yabancı diller arasında Türkçenin gerek coğrafi konumlarının yakınlığı gerekse tarih 
boyunca sürdürülen ticari, siyasi ve kültürel ilişkilerin etkisiyle en çok deyim alışverişinde bulunduğu dil şüphesiz Farsçadır.

Deyim, genellikle bir durumu, karşılaşılan olayların özelliklerini, insan karakter ve davranışlarını, insanların çeşitli fiziksel ve ruhsal niteliklerini betimlemek üzere benzetme ya da aktarma denilen anlam olaylarından yararlanarak oluşturulan, sözü daha etkili bir biçimde söylemeye yarayan bir yapıdır. Örneğin "ölmek” eyleminin anlatımı esnasında eylemin yıkıcı etkisini azaltmak amacıyla genellikle ad aktarmaları yoluyla deyimlerden faydalanılır: hayata gözlerini yummak, rahmetli olmak, vadesi dolmak... Türkçede yaygın deyim yapma yollarından bir diğeri de aralarında benzetme ilgisi kurulan iki şeyin gibi edatı ya da dönmek eylemlerinin yardımıyla oluşturulmasıdır: Çarşamba pazarı gibi, dut yemiş bülbüle dönmek... Buradaki birkaç örnekten de anlaşılacağı üzere, Türkçede her ne şekilde oluşturulsa oluşturulsun deyimlerin çoğunlukla bir eylem ile bittiği görülmektedir. Aynı durum Farsça için de söylenebilir. Farsça deyimler incelendiğinde onların da Türkçedeki gibi aralarında benzerlik ilgisi bulunan başka bir şeye benzetilerek aktarma yoluyla ve çoğunlukla eylemler yardımıyla oluşturulduğu görülebilir.

Bu çalışmada Eski Anadolu Türkçesi dönemine ait olan Hoca Mes'ud'un Ferhengnâmeyi Sa'dî Tercümesi adlı eseri ile Sa'dî'nin Farsça Bostan adlı eseri arasındaki benzerlik, bazı beyitler birebir karşılaştırılarak ortaya konacak ve özellikle iki dildeki deyim benzerlikleri bu iki eser üzerinden açıklanmaya çalışılacaktır.

\section{FERHENGNÂME-Yİ SA'DÎ TERCÜMESİ VE ESERİN BOSTAN İLE BENZERLİĞI}

Ferhengnâme-yi Sa'dî Tercümesi, Hoca Mes'ud bin Ahmed tarafından 1354/1355 (H. 755) yılında Farsçadan Türkçeye (Eski Anadolu Türkçesi) yapılan tercüme bir eserdir. Hoca Mes’ud eserin konusunu İranlı şair Sa'dî-yi Şirâzî’nin 1257 yılında yazdığı Bostan adlı didaktik eserinden almıştır. Ahlaki, siyasi, dinî, toplumsal ve günlük yaşantıya dair pek çok öğüdün bulunduğu mesnevi Fars edebiyatı için önemli bir eserdir. Hoca Mes'ud'un yaptığı çeviri ise döneminin dil özelliklerini ve söz varlığını yansıtması bakımından Eski Anadolu Türkçesi için mühim bir eser olmasına karşın üzerinde yeterince çalışma yapılmamıştır.

Ferhengnâme-yi Sa'dî Tercümesi'nin bugün Millet Kütüphanesi Ali Emîrî nüshası, Kopenhag nüshası, Manisa nüshası ve Köprülü’nün gördügünü söylediği nüsha olmak üzere toplam dört nüshası bilinmektedir (Şan, 2013: 205-208).

Hoca Mes'ud 4044 beyitten oluşan Bostan'ın tamamını değil, yaklaşık 1000 beyitlik bir seçkiyi aynı vezinde mütekârib bahriyle (feûlun feûlun feûlun feûl) yazmıştır. Eserini yazmaya karar verme sürecini şu beyitlerle anlatmaktadır:

oturur-iken bir gün evümde ben

hem inen melül-idüm ol-demde ben (Kopenhag: 42. beyit) 
oḳıdumdı ferheng-nāme sözin

ki Sa'dī düzüpdür anı aysuzın (Kopenhag: 44. beyit)

ögüme düşe geldi dédüm hele

n'ola bu dahı türkiye ger gele (Kopenhag: 45. beyit)

ki Bostān içinden üzülmiş-durur

üküş hoş ögütler dizilmiş-durur (Kopenhag: 46. beyit)

Eserin sebeb-i telif bölümünde de belirttiği gibi tercüme esnasında mümkün olduğunca ana metne sadık kalmaya çalışmış, birebir tercüme etmeye gayret etmiştir. Eserin Farsça ya da Türkçe olmasının bir önemi olmadığını, önemli olanın sözün bir anlam içermesi ve doğru olması gerektiğini ifade etmiştir.

ne dilce olurisa ma 'nādur aṣl

kim anuך-içün ḳodılar bāb u faṣl (Kopenhag: 33.beyit)

gerek söz ola ma 'nilü vü oyat tefāvüt degül dèrse türk ü țat (Kopenhag: 34. beyit)

Hoca Mes’ud, tercümesini yaparken özellikle Türkçe kelimeler kullanmaya özen gösterdiğini, yabancı kelimeleri eserine almadığını vurgulamıştır:

anuy degme bir beytine tercüme

dèrüp yad sözi sürmedüm harcuma (Kopenhag: 50. beyit)

Hoca Mes'ud okuruna seslenerek inanmayanların eserini Farsçadaki biçimiyle karşılaştırmalarını, bu esere ne kadar emek verdiğini, Farsçadan Türkçeye nasıl doğru düzgün geçtiğini, biçim ve mana bakımından Farsçasıyla bir uyum içinde olduğunu görmelerini salık vermiştir:

èy söz bilen inanmazısay șına

muḳābil getür oşda țatcasına (Kopenhag: 52. beyit)

göresüz ki eylemidür dèdügüm

belüre ne-dẹlü emek yédügüm (Kopenhag: 53. beyit)

ki her beyti yèrlü yèrince dürüst

nète tatcadan türkiye geldi cüst (Kopenhag: 54. beyit)

ger ayruksı oldıyısa ḥarf u șavt

az olmış ola nesne ma 'näda fevt (Kopenhag: 55. beyit) 
Yukarıdaki beyitlerden de anlaşılacağı gibi Hoca Mes'ud eserini yazmaya karar verdiği kitabın orijinal Bostan değil, onun içinden seçme beyitlerle oluşturulan "muhtasar" minvalinde bir eser okuduğundan bahseder. Fuad Köprülü ve Kilisli Muallim Rifat da Hoca Mes'ud'un bu sözlerinden yola çıkarak Farsça pek çok Bostan muhtasâr (kısaltılmış olan) ve müntehâbı (seçmece olan) incelediklerini ancak hiçbirinin Hoca Mes'ud'un yazdığı eserle uyumlu olmadığını söylemişlerdir (Şan, 2013: 203-222). Biz de uzun süredir yaptığımız çalışmalar neticesinde maalesef Hoca Mes'ud'un eseriyle birebir örtüşen bir Farsça nüshaya rastlayamadık.

Eserin her ne kadar orijinalini bulamamış olsak da metni orijinal Bostan ile karşılaştırdığımızda beyitlerin Farsça ve Türkçe anlamlarının birebir örtüştüğünü görürüz. Diğer bir değişle, Hoca Mes'ud'un dediği gibi eser, Farsçası ile aynı vezinde ve anlamda da pek değişiklik olmadan çevrilmiştir. Kilisli Muallim Rifat’ın yayımladığı nüshada bazı beyitlerin Farsça biçimleri de dipnotta verilmiştir. Bu beyitlerin Farsça ve Türkçe biçimleri karşılaştırıldığında bazı beyitlerin tamamen aynı oldukları gözlemlenmiştir:

dekin oturu gezme çevre yaya

ki yuvalansa țaş ot yapışmaz aya (Kopenhag: 579. beyit)

(Boş oturup çevreyi dolanma; çünkü taş yuvarlanırsa ot ona yapışmaz.)

sukūnī bed-est āvāre-ye bī-sebāt

ki bir seng gerdān ne-revìd nebāt (Rifat: s. 51)

eger pādişāhdur ve ger eskici

atar tạ toḳınsa ahşam ucı (Kopenhag: 631. beyit)

(Padişah ya da eskici olsa da fark etmez, akşamın ucu dokununca tan başlar)

eger pādişāh-est ve ger pīne dūz

çü haftand gerd dişeb her do rüz (Rifat: s.55)

kaç andan ki söyleye on ürce söz

oyat bir sözüy yèg [ki] on ürce söz (Kopenhag: 661. beyit)

(On tane boş söz söyleyen adamdan kaç; bir doğru sözün on tane boş sözden iyidir)

hazar kon zenādānde merde gūy

çü dānāyit-ki gūy vìrverde gūy (Rifat: s.57)

şeşe Rahş̧an bir puluç olsa bend

dutamaya yüz Rüstem atup kemend (Kopenhag: 670. beyit)

(Yüz tane Rüstem olsa kement atıp tutamazken bir aciz Rahş’ın bendini çözer.) 
yekī țfl berdārdāz Rahş bend

ne-yāyed bașad Rüstem ander kemend ${ }^{1}$ (Rifat: s. 58)

katumda benüm uṣlu ol gişidür

ki gendüye olmak dümük işidür (Kopenhag: 701. beyit)

(Benim gözümde akıllı kişi, -başkasıyla uğraşmayıp- kendi işine bakandır)

kesī pişs-e men der-cihān 'ākil-est

ki meşğūl hod ve ez-cihān ġăfil-est (Rifat: s.60)

güli görse düşer muhakkıı gözi

degül güle gendüye göyner özi (Kopenhag: 928. beyit)

(Tahkik edenin gözü gülü görse aciz kalır. Güle değil kendine yanar)

muhakkkı çü ber merde rịzed güleş

ne be-rūy ki ber hod be-sūzed dileş (Rifat: s.80)

eger muhtesib görse kayura hem

gişi-kim țaşıdur terāzūda kem (Kopenhag: 979. beyit)

(Terazideki taşı az olan kişiyi, hesap memuru görünce üzülüp tasalanır)

eger muhtesib kerded an-rā gam-est

ki seng-i terāzū-yı bāreş kem-est (Rifat: s.85)

Rifat yukarıda da görüldüğü gibi bazı beyitlerin Farsça karşılıklarını dipnotlarda vererek beyitlerin Türkçe ve Farsça benzerliklerinin ve farklılıklarının ortaya konmasına katkı sağlamıştır. Bu çalışmada Rifat'ın birkaç beyitle sınırlı bıraktığı bu yöntem genişletilerek daha fazla beyit karşılaştırılmış, aralarındaki benzerlik ve farklılıklar incelenmeye çalışılmıştır.

götürmez-mi-di yèl her șubḥ u şām

Süleymān serīrin 'alayhi's-salām (Kopenhag: 72. beyit)

(Rüzgâr, her sabah ve akşam Süleyman'ın tahtını -bir yerden bir yere- götürmüyor muydu?)

ne ber bād reftī sehergāh u şām

serīr-i Süleymān 'aleyhi s-selām (Bostan: s. 83/13. satır)

becid eyleme dīvār öyinde lāg

ki dīvāruy ardında olur kulag (Kopenhag: 663. beyit)

1 Muallim Rifat Farsça orijinalini verdikten sonra dipnotta şu açıklamayı yapmıştır: atạ yularını bağından bir çocuk çözebilir, fakat bir kere at kaçdı mı yüz Rüstem maharatında dilāver kemend atıp onu yakalayamaz. buluç ise innin kimsedir. Burada maksat ‘āciz, za ịf, güçsüz insandır. Rahş Rüstem'in atının adıdır. "Rüstemin Rahş adlı atı var idi, eyle bil kim gendüziyle yar idi” Âşık Paşa’nın sözü (RİFAT, 1340-1342 (M.1921-1922): 58). 
(Duvar önünde şakayı hemen söyleme; çünkü duvarın arkasında kulak vardır -yerin kulağı vardır-).

me-kon pey-deş dīvār ġybet besī

kesī būd ki-ez pes-eş gūş dāred kesī (Bostan: s.273/5. satır)

ganīmet bil oş [kim] urursin nefes

çü kuş uça ne işe yarar kafes (Kopenhag: 925. beyit)

(Nefes almayı ganimet bil; kuş uçarsa kafes neye yarar?)

çü țūṭi kelāgeş būd hem nefes

ganīmet şomāred hāāạs ez kafes (Bostan: s. 292/4. satır)

yigitlikde urduy-ısa el ayak

kocalıkda ögüy dèr ü hakka bak (Kopenhag: 907. beyit)

(Gençliğinde el ayak vurduysan (çabaladıysan), ihtiyarlığında aklını topla ve Hakka bak!)

eger der cevānī zedī dest o pāy

der eyyam-e pīrī be heş bāş o rāy (Bostan: s. 338/13. satır)

gęçenler üzerine her bir nefes

teferrüclenüben geçürdü̈ heves (Kopenhag: 910. beyit)

(Her bir saniye gelip geçenlerle eğlenip heves geçirdin)

teferrüc konān der hevā-yi heves

gozaştem ber hāk bisyār kes (Bostan: s. 339/5. satır)

ber ol yèr kim èy Sa'dī ag̉aç diken

döger hırmanı ol-ki tohmın eker (Kopenhag: 986. beyit)

(Ey Sa'dî, ağaç diken yemiş yer, tohum eken harman döver)

ber ān hored Sa 'dì ki bīhī nişāned

kesī bored ḥırman ki tohmmī feşāned (Bostan: s.364/4. satır)

\section{METINDE KULLANILAN DEYIMLER}

Eser üzerinde uzun süredir devam eden dil incelememiz sırasında dikkatimizi çeken unsurlardan biri de metinde kullanılan deyimlerdir. Kullanılan deyimlerin pek çoğu Farsçada da yaygın biçimde kullanılan deyimlerin birebir karşılıkları gibidir. Elimizde Hoca Mes'ud'un tercüme ettiği nüsha olabilseydi beyitler ve deyimlerin birebir karşılaştırmasını daha kolay yapabilirdik. Ancak Köprülü ile Rifat'ın da belirttiği gibi Hoca Mes'ud'un eserine konu olan 
örnek bulunamamıştır (Şan, 2013; 203-222). Bu sebeple bu çalışmamızda Ferhengnâmeyi Sâdi Tercümesi'nde tespit edebildiğimiz deyimler, Sa'dî’nin Bostan eseri esas alınarak karşılaştırılmaya çalışılmıştır.

Türkçenin Anadolu'da yazı dili olma sürecinde Hüsrev ile Şirin, Mantıku't-Tayr, Leyla ile Mecnun, Yusuf ile Züleyha gibi pek çok eser Farsçadan Türkçeye çevrilmiştir. Bu çeviri faaliyetleri sonucunda pek çok Farsça yapı, tamlama ve kelime Türkçede de yaygın biçimde kullanılmaya başlanmıştır. Farsçadan Türkçeye geçen bu yapı örneklerinden biri de şüphesiz deyimlerdir. Bugün Türkçede hâlâ kullanımda olan pek çok deyimin karşılı̆̆ı Farsçada da vardır. Bu deyimlerin metinler yoluyla Farsçadan mı Türkçeye yoksa sözlü yolla Türkçeden mi Farsçaya geçtiği meselesi tartışmalıdır. Ancak yazılı metinlere dayanarak Türkçede kullanılan bazı deyimlerin bu çeviri faaliyetleri sırasında Türkçeye geçmiş ve Türkçede de yaygınlık kazandığı düşünülebilir. Başka bir olasılıkla Hoca Mes’ud eseri çevirirken o dönemde zaten Türkçede de kullanılan deyimleri kullanmayı seçerek metni daha anlaşılır kılmaya aynı zamanda da Farsça metne sadık kalmaya çalışmış olmalıdır. Ferhengnâme-yi Sa'dî Tercümesi de 14. yüzyılda Eski Anadolu Türkçesi döneminde yazılmış ve Farsça Bostan eserinden çevrilmiş olması dolayısıyla Farsça ile ortak kullanım alanı olan ve yapı olarak benzerlik gösteren pek çok deyim içermektedir. Bu deyimlerden bazıları ve Farsça Bostan eserindeki karşılıkları şöyledir:

dilün çek-: dilini tutmak, susmak

zabān dar kashīdan: to keep in one's tongue (Steingass: s.608/2. sütun) zabān kelimesi Farsçada "dil", kashīdan fiili ise kelime anlamı olarak "çekmek" demektir. İki sözcüğün bir araya gelmesiyle ortaya çıkan mecaz anlam Türkçeye de aynı yolla kazandırılmıştır.

dilüy çek eger var-isa sende hüş

yā Sa'dī bigi söyle yā ol hamūş (Kopenhag: 690. beyit)

(Şuurun yerindeyse dilini tut! Ya Sa'dî gibi söyle ya da sessiz ol!)

çü Sa'dī kesī żevk halvet çeşìd

ki ez her ki 'ālem zebān der keşìd (Bostan: s.292/13. satır)

el ayạ̣ ur-: (elde edilemeyecek bir şey için) çırpınmak, çabalamak

dast u pā zadan: to beg with importunity (Steingass: s.521/1. sütun)

Farsçada kelime anlamı olarak dast el, $p \bar{a}$ ayak, zadan ise "vurmak" anlamı taşır. Kelime anlamı olarak el ve ayaklarıyla vurmak gibi bir anlama gelen deyim, kelimelerin Farsçada da Türkçedeki anlamı gibi "bir işi elde etmek uğruna çok çabalamak, uğraşmak, bir işi elde etmek için tepinmek” gibi anlamlar içermektedir.

yigitlikde urduy-ısa el ayak

kocalıkda ögüy dèr ü Hakka bak (Kopenhag: 907. beyit) 
(Gençliğinde çırpınıp başaramadıysan, ihtiyarlığında aklını topla ve Hakka bak!)

eger der cevānī zedī dest o pāy

der eyyam-e pīrì be heş bāş o rāy (Bostan: s. 338/13. satır)

yẻle gèt-: boşa gitmek, mahvolmak

bar bād raftan: to perish (Steingass: s.137/2. sütun)

Farsçada $b \bar{a} d$ "rüzgâr", raftan ise "gitmek" demektir. Kelime anlamı olarak "rüzgârda gitmek" gibi bir anlamı olan deyim, bir işin rüzgârla beraber savrulması, boşa gitmesi, yok olması" gibi anlamlar kazanmıştır.

gel èy kim senüy yètmişe yètdi ‘̈mmür

meger uyır-ıduך yèle gètdi ‘̈mür (Kopenhag: 899. beyit)

(Ey ömrü yetmişe dayanan sen, gel! Uyuduğun için ömrün yele gitti -boşa gitti-.)

beyā ey ki ‘̈mret be heftād reft

meger hafte būdī ki ber bād reft? (Bostan: s.335/7. satır)

Yukarıda ismi geçen deyimler görüldüğü gibi Farsça deyimlerin Türkçeye yapılmış birebir karşılıklarıdır. Hoca Mes'ud gerçekten de eserinde ifade ettiği gibi eseri olduğu gibi çevirmeye, biçim ve manada en az değişiklik yaparak tercümesini oluşturmaya gayret etmiştir. Adı geçen beyitler haricinde metinde Farsça biçiminden örnek alınarak Türkçeye uyarlanmaya çalışılan beyitlerde bazı isimler birebir alınmış ve isme bir Türkçe fiil getirilerek deyim oluşturulmuştur.

'ahd și-: yemin bozmak

'aḥd şikesten: şikesten-i peymān u naḳż-i 'aḥd.

Deyim Farsçada Arapça kökenli bir kelime olan "yemin, ant” anlamına gelen 'ahd ile Farsçada "kırmak" anlamına gelen şikesten fiiliyle kullanılmaktadır.

Hudāya üküşşımışam 'ahdler

każā-y-lla nète édem cehdler (Kopenhag: 1028. beyit)

(Ey Allah'ım çok yeminler bozmuşum, kaderle nasıl uğraşırım?)

cem' ḳıl-: bir araya getirmek, toplamak

cem 'kerden: emval bisyār cem' kerd, gerd kerden.

jam'kardan: to assemble, bring together, collect (m.c.) (Steingass: s.371/2. sütun)

Deyim Farsçada Arapça kökenli bir kelime olan cem 've "yapmak, etmek" anlamına gelen Farsça kerden fiiliyle kullanılmaktadır. 
țaġlmış göyülleri sen cem ' ḳl

ki cem 'iyyetüyden üzülmeye kıl (Kopenhag: 301. beyit)

(Dağılmış gönülleri sen topla; çünkü sen topladığında bir kıl bile kopmaz.)

fevt ol-: kaybolmak, yitmek

fevt şoden: ez-beyn reften, ez-dest reften.

Deyim Farsçada Arapça kökenli bir kelime olan, "bir şeyi kaybetme, elden kaçırma" anlamına gelen fevt ile Farsça "olmak" anlamına gelen şoden fiiliyle kullanılmaktadır.

ger ayruksı oldl-y-lsa ḥarf u șavt

az olmış ola nesne ma 'nāda fevt (Kopenhag: 55. beyit)

(Her ne kadar harfleri ve sesleri farklıysa da manada pek bir şey kaybolmamıştır.)

ġușṣa yè-: kederlenmek

gușṣa horden: gam u endūh horden.

Deyim Farsçada Farsça kökenli bir kelime olan ve "keder" anlamına gelen ġușşa ile "yemek" anlamına gelen Farsça horden fiiliyle kullanılmaktadır.

üküş gușşa ye vü çevürme yüzi

apılayl-gör bir gişi 'çün yüzi (Kopenhag: 328. beyit)

(Bir kişinin gönlünü hoş tut, onun için üzül, ondan yüzünü çevirme!)

yèseり ġușa gündüz kayurma èy yār

gèce çün yanuyda ola ġam-güsār (Kopenhag: 718. beyit)

(Ey dost, gündüz canın sıkılırsa endişelenme, çünkü geceleri dert ortağın yanındadır.)

hırman dög-: Ekin tanelerini saptan ayırma işini yapmak

khirman zadan: to stack corn (Steingass: s.457/1. sütun)

hirman borden: istifade ez-hirman kerden, hirman be-dest āverden.

Deyim Farsçada Farsça kökenli bir kelime olan ve "harman" anlamına gelen hirmen ile "vurmak, dövmek" anlamına gelem Farsça zeden fiiliyle kullanılmaktadır. Bostanda ise deyim "taşımak" anlamına gelen borden fiiliyle kullanılmıştır. Ancak Türkçede "harman taşımak" gibi bir deyim olmadığı için onun yerine hirmen zeden deyiminin karşılığı olan hıırman dögmek kullanılmıştır.

ber ol yèr kim èy Sa 'd̄̄ àgaç diken

döger hırmanı ol-ki tohmın eker (Kopenhag: 986. beyit) 
(Ey Sa'dî, ağaç diken yemiş yer, tohum eken harman döver.)

ber ān hored Sa 'dī ki bīhī nişāned

kesī bored ḥırman ki tohmī feşāned (Bostan: s.179)

istimā' èt-: dinlemek

Deyim Farsçada Arapça kökenli bir kelime olan ve "duyma" anlamına gelen istimā ile Farsça kerden fiiliyle kullanılmaktadır.

istimā' kerden: şenīden, gūş dāden.

nedür dèmezem èy karındaş semā

meger bileven kim éder istimā' (Kopenhag: 431. beyit)

(Ey kardeş, eğer işitenin kim olduğunu bilirsem, işitilen nedir diye sormam.)

murād al-: arzusuna kavuşmak

mūrād berdāşten: kām giriften, be kām resīden.

Deyim Farsçada Arapça kökenli bir kelime olan murād ile Farsçada "almak" anlamına gelen berdāşten fiilinin birleştirilmesiyle kullanılmaktadır.

cihāndan şu kimse murādı ala

ki yārl-y-ıla bir gönülde ola (Kopenhag: 720. beyit)

(Kalpleri birbiri için atan bir sevgiliyle olan kişi, bu dünyada arzusuna kavuşmuştur.)

nefes ur-: nefes almak

nefes zeden: nefes keşiden, zendegī kerden.

nafas zadan: to breathe (Steingass: s. 1416/1.sütun)

Deyim Farsçada Arapça kökenli bir kelime olan nefes ile Farsçada “vurmak" anlamına gelen zeden fiiliyle kullanılmaktadır.

ganīmet bil oş [kim] urursin nefes

çü kuş uça ne işe yarar ḳafes (Kopenhag: 925. beyit)

(Nefes almayı ganimet bil; kuş uçarsa kafes neye yarar?)

çü tụțì kelāgeş būd hem nefes

ganīmet şomāred hāāāṣ ez kafes (Bostan: s. 143)

teraḥ̣üm eyle-: merhamet etmek

teraḥhum kerden: bahşīden, raḥm āverden, raḥm kerden, şefḳat kerden tarahhum kardan: to pity, to spare (Steingass: 293/2. sütun) 
Deyim Farsçada Arapça kökenli bir kelime olan ve "bağışlama" anlamına gelen teraḥhum ile Farsça kerden fiilinin birleştirilmesiyle kullanılmaktadır.

teraḥü̈m sen eylemegil ẓālime

aya rạ̣metüy zulmdür 'āleme (Kopenhag: 339. beyit)

(Zalime merhamet etme! Ona rahmet etmen demek dünyaya zulüm etmek demek olur.)

ümīd üz-: (bir şeyden) ümit kesmek, ummayı bırakmak

ümīd borīden: nevmīd şoden, ümīd berhāsten.

umed-rā pai burīdan: to lose hope (Steingass: s.101 (2. sütun)

bahīlü̈ elindeki altun henüz

taş içindedür andan ümīdü円 üz (Kopenhag: 325. beyit)

(Cimrinin elindeki altın taş içindedir, ondan ümidini kes!)

yād èt-: hatırlamak, anmak

yād kerden: be-hāạtır āverden, be yād āverden

Deyim Farsçada Farsça kökenli bir kelime olan ve "anma, hatırlama” anlamına gelen yād ile Farsça kerden fiilinin birleştirilmesiyle kullanılmaktadır.

og̀ul çün-ki dükede on yaşını

yād ètme ādem anuy yoldaşını (Kopenhag: 744. beyit)

(Ey insan, oğlan on yaşını bitirince onun yoldaşını anma!)

Yukarıdaki beyitlerin haricinde metinde hem isim kısmı hem de fiil kısmı Türkçe olan Farsça birebir kelime karşılıkları bulunan deyimler de vardır:

baş çek-: itiraz etmek, kafa tutmak, kabul etmemek

ser keşīden: kabūl ne-nemūden, nā-fermānī kerden, ser berdāşten.

sar kashīden: to disobey (Johnson:691/3. sütun)

Deyim Farsçada Farsça kökenli bir kelime olan ve "baş, kafa" anlamı taşıyan ser ile Farsça "çekmek" anlamına gelen keşīden fiiliyle kullanılmaktadır.

Türkçede "herhangi bir konuda önde gitmek, önayak olmak" anlamıyla kullanılan deyim, bu metinde Türkçedeki anlamına göre değil, tamamen Farsçadaki anlamına göre kullanılmıştır.

kadem ilerürek baṣu gökden aş

gèrü kalma hayvānlayın çekme baş (Kopenhag: 982. beyit) 
(Daha ileri adım atıp göğü aş; hayvan gibi geri kalıp kafa tutma!)

boyun ver-: buyruk altına girmek

gerdan dāden: iṭā at kerden, muṭ̣̂ şoden, teslim şoden.

Deyim Farsçada Farsça kökenli bir kelime olan gerdan ile Farsça “vermek” anlamına gelen dāden fiiliyle kullanılmaktadır.

bu düşmenler olursa saya kavī

boyun verrmeyüp yagmalarlar evi (Kopenhag: 652. beyit)

(Bu düşmanlar senden güçlü olunca buyruk altına girmeyip evi yağmalarlar.)

dil yu-: “gönlünü yıkamak”, vazgeçmek, terk etmek

dil şosten: șarf-1 naẓar kerden, dest keşīden.

Deyim Farsçada Farsça kökenli bir kelime olan ve "gönül” anlamına gelen dil ile Farsça "yıkamak" anlamına gelen şosten fiilinin birleştirilmesiyle kullanılmaktadır.

eger yatlu sözden dilüy yuyasin

yég andan ki yüz kez elụ̈ yuyasın (Kopenhag: 697. beyit)

(Kötü sözden dilini yıkaman -kötü sözden uzak durman- yüz kez elini yıkamandan daha iyidir.)

el yu-: kötü bir şeyden uzak durmak, onu yapmaktan vazgeçmek

dast shustan: to abonden (Steingass: s.521/1.sütun)

Deyim Farsçada Farsça kökenli bir kelime olan ve "el” anlamına gelen dest ile Farsça "yıkamak" anlamına gelen şosten fiilinin birleştirilmesiyle kullanılmaktadır.

eger 'āşılk-ısay azıtma yoluy

yuğll Sa'di bigi garė̇den elüy (Kopenhag: 448. beyit)

(Eğer âşık isen, yolunu şaşırma! Sa'dî gibi kinden intikamdan uzat dur!)

elden ḳo-: elden birakmak, terk etmek, birakmak

ez-dest guzāşsten: nihāden, dest berdāşten, ve guz̄āşten.

az dast guzashtan: to give up, to abandon (Steingass: s.521/1. sütun)

Deyim Farsçada Farsça kökenli bir kelime olan ve "el” anlamı taşıyan dest sözcügüne Farsça ez+ ablatif ekinin eklenmesi ve Farsça "bırakmak" anlamına gelen gużāşten fiiliyle Türkçedekine çok benzer bir yapıyla kullanılmaktadır. 
çü devrān géçüp kırḳa yètdi yaşuך

șu başdan aşar koğll elden işü̈ (Kopenhag: 908. beyit)

(Zaman geçti ve yaşın kırka dayandı; artık yapacak bir şey kalmadı, işini bırak,-artık çabalama-)

bu yolda azltmaya ol gendüzin

kim elden komaya kulāvuz izin (Kopenhag: 21. beyit)

(O kendisini bu yoldan saptırmasın, kılavuzu takip etmeyi bırakmasın.)

gọ̈ül vèr-: sevmek, ilgi duymak.

dil dāden: 'āşı̣ şoden, 'alāḳa yāften.

dil dadan: to inspire with courage, to heraten; to fall in love with; to allow, to permit (Steingass: s. 531/1. sütun)

Deyim Farsçada Farsça kökenli bir kelime olan ve "gönül” anlamı taşıyan dil ile Farsça "vermek" anlamına gelen dāden fiiliyle kullanılmaktadır.

\section{bulara gönül vérmeye ehl olan}

ki dāyim düzenlikleridür yalan (Kopenhag: 886. beyit)

(İşi bilen bunlara gönül vermesin; çünkü işleri hep yalandır.)

göyül vèrme bu yérde hoş yatma sen

çü günbedde koz țayınur ètme sen (Kopenhag: 934. beyit)

(Bu yeri sevme, burada hoş yatma; ceviz kümbette kayar, yapma sen.)

oda ur-: ateşe vermek, yakmak

àteş zeden: sūzānīden, āteş enderzeden.

Deyim Farsçada Farsça kökenli bir kelime olan ātiş ile yine Farsça kökenli “vurmak" anlamına gelen zeden fiilinin birleştirilmesiyle kullanılmaktadır. Bu kullanıma ek olarak Türkçede isme $+e$ datif eki eklenmiştir.

atası ḳaḳyup düşermiş uda

düdügini anuך ururmış oda (Kopenhag: 440. beyit)

(Babası bağırıp çağırınca utanırmış düdüğünü ateşe atmış.)

țuş ol-: mutabık olmak, muvafik olmak, denk olmak

rū-be-rū şoden: muvācih şoden, muḳābil şoden, nezdīk yek-diger āmeden. 
Deyim Farsçada Farsça kökenli bir kelime olan ve "karşı karşıya, yüz yüze" anlamı taşıyan $r \bar{u}$-be-rū ile Farsça “olmak” anlamına gelen şoden fiiliyle kullanılmaktadır.

nète ayruluk șabr-ıla ola țuş

ki geฑsüzin ayruluk olur üküş (Kopenhag: 414. beyit)

(Ayrılık nasıl sabra denk olur? Gönülsüz ayrılık daha fazla gelir.)

uda düş-: utanmak

be-şerm üftāden: şermende şoden, hâlet-i şerm u hicālet dest dāden

Deyim Farsçada Farsça kökenli bir kelime olan ve "utanma" anlamı taşıyan şerm sözcüğüne Farsça $b e+$ datif ekinin eklenmesi ve Farsça "düşmek" anlamına gelen üftāden fiiliyle Türkçedekine çok benzer bir yapıyla kullanılmaktadır.

atası ḳakıyup düşermiş uda

düdügini anuy ururmış oda (Kopenhag: 440. beyit)

(Babası bağırıp çağırınca utanırmış düdüğünü ateşe atmış.)

yele vẻr-: mahvetmek, yok etmek

be bād dadan: to ruin, to destroy (Steingass: s.137/2. sütun)

Deyim Farsçada Farsça kökenli bir kelime olan ve "rüzgâr, yel" anlamı taşıyan bād sözcüğüne Farsça be+ datif ekinin eklenmesi ve Farsça "vermek" anlamına gelen dāden fiiliyle Türkçedekine çok benzer bir yapıyla kullanılmaktadır.

néçe devlet issi ki oyun-ıla

utuzup verrür devletini yele (Kopenhag: 248. beyit)

(Nice devlet sahibi bir oyunla yenilip devletini kaybeder.)

nęçe ḳızl altunı vèrür yèle

ki bir bakırı altun ède-bile (Kopenhag: 394. beyit)

(Bir bakırı altın edebilecekken nice kızıl altını savurur.)

yüzin țuruş èt-: yüzünü buruşturmak, surat asmak, kaşlarını çatmak

rūy turuş kerden: çīn ber ebrū efkenden, rūy-rā be 'alāmet-i ḩaşm der hem keşīden. rūy turush kardan: to frown at, to be vexed with (Stengass: s.597/2. sütun)

Deyim Farsçada Farsça kökenli bir kelime olan ve "yüz, surat” anlamına gelen rūy ile yine Farsça kökenli “ekşi”” anlamına gelen turuş ve Farsça kerden fiilinin birleştirilmesiyle kullanılmaktadir. 


\author{
dédi öldügüm açlıg่-lla üküş \\ yèg andan-ki ol yüzin éde turuş (Kopenhag: 606. beyit)
}

(Dedi ki açlıktan öldüğüm çok olmuştur, yüzünü buruşturmasındansa açlıktan ölmeği yeğlerim.)

\title{
SONUÇ
}

Türk ve Fars toplumu geçmişten günümüze kültürel, siyasi, sosyal etkileşimine devam etmiş, birbirlerinin kültürüne pek çok yeni unsur katmış iki topluluktur. Bu etkileşimin en güçlü örneklerinden ve ispatlarından biri kuşkusuz dildeki etkileşimdir. Bu iki dil arasındaki ilişki muhtemelen Oğuzcanın henüz yazı dili olmadığı dönemde başlamış olmalıdır. Çok eski dönemlerden başlayarak bazı kelimeler Farsçaya geçmiş, aynı şekilde pek çok Farsça kelime ve yapı da Türkçeye geçmiştir. Farsçadan Türkçeye geçen bu kelime ve yapılarda Eski Anadolu Türkçesi döneminde Farsça orijinallerinden tercüme ya da adapte edilen eserlerin katkısı büyüktür. Bu eserlerden biri de Hoca Mes'ud'un kendisinin de eserinde belirttiği gibi anlama mümkün olduğunca bağlı kalarak Sa'dî'nin Bostan adlı eserinden çevirdiği Ferhengnâme-yi Sa'dî Tercümesi'dir.

Hoca Mes'ud eseri çevirirken bazı beyitleri kelimesi kelimesine çevirmiştir. Bu çeviri sırasında eserin Farsça orijinalinde bulunan deyimler de aynı şekilde Türkçeye aktarılmıştır. Her iki eserdeki benzer beyitler incelendiğinde Hoca Mes'ud'un çoğu deyimi anlama odaklanarak çevirmek yerine kelimesi kelimesine çevirdiği görülür. Onun dışındaki deyimler de her ne kadar eserde aynı biçimde geçmiyorsa da Farsçada kullanılan deyimlerdir. Bu deyimlerin bazıları hem isim kısmı hem de fiil kısmı Türkçe olan Farsça birebir kelime karşılıkları bulunan deyimler (el ayak ur-/dast u pā zadan "çırpınmak, çabalamak"), bazıları da isim kısmı aynen bırakılmış yanına Türkçe fiil getirilerek oluşturulan deyimler (g்șșa yé-/ gușṣa horden "kederlenmek") olarak karşımıza çıkar.

Sa'dî’nin ve Hoca Mes'ud'un eserleri incelendiğinde deyimlerin hem Türkçe hem de Farsçada ifadeyi güçlendirmek için anlatımda sıkça başvurulan bir yöntem olduğu rahatlıkla söylenebilir. Benzer anlam ve yapıdaki deyimlere her iki dilde de rastlanması, aslında bu iki dilin ortak değerlerinin birbirine ne kadar yakın olduğunu göstermektedir. İki dil arasındaki deyim ortaklığı, iki toplumun yaşam ve düşünce biçiminin birbirine yakınlığına işaret etmektedir.

\footnotetext{
Hakem Değerlendirmesi: Dış bağımsız.

Çıkar Çatışması: Yazar çıkar çatışması bildirmemiştir.

Finansal Destek: Yazar bu çalışma için finansal destek almadığını beyan etmiştir.
}

Peer-review: Externally peer-reviewed.

Conflict of Interest: The author has no conflict of interest to declare.

Grant Support: The author declared that this study has received no financial support. 


\section{KAYNAKÇA/REFERENCES}

Aksan, D. (1962). Anlam Alışverişi Olayları ve Türkçe, Türk Dili Araştırmaları Ylllığı-Belleten, 9, 207-273.

Aksan, D. (2002). Anadilimizin Söz Denizinde, Ankara: Bilgi Yayınevi.

Aksan, D. (2013). Türkçenin Gücü, Ankara: Bilgi Yayınevi. [ilk baskı: 1987]

Aksoy, Ö. A. (1971-1976). Atasözleri ve Deyimler Sözlüğ̈̈, Ankara: Türk Dil Kurumu.

Büke, H. (2019). Ferhengnâme (Kilisli Muallim Rifat ve Veled Çelebi), X. Uluslarası Dünya Dili Türkçe Sempozyumu Bildiri Kitab1, 349-352.

Clauson, S. G. (1972). An Etymological Dictinary of Pre-Thirteenth-Century Turkish, Oxford.

Dekhodâ, A. (1931). Loghatnâme, Tehran: Tehran University Publication.

Deny, J. (2012). Türk Dili Grameri (Osmanlı Lehçesi), (Çeviren: Elöve, A. U.), İstanbul: Kabalcı Yayınevi. [yeniden dizilmiş bask1].

Derleme Sözlüğ̈̈̈. (1963-1982) Ankara: Türk Dil Kurumu.

Dilçin, C. (1991). Süheyl ü Nevbahar, inceleme-metin sözlük, Ankara: Türk Dil Kurumu.

Erkan, M. ve Özkan, M. (1998). Hoca Mesud, Türk Diyanet Vakfi İslâm Ansiklopedisi, C. 18, İstanbul, 189-191.

Ferhengnâme-yi Sa'dî Tercümesi, Kitāb-ı ferheng-nāme ez güftār-ı Hoca Mes'ūd, Det Köngelige Bibliotek, Copenhagen/Denmark. Cod.Turc. 20.

Gülenç, H. (2010). Ferhengnâme-i Sadî, Manisa: Celal Bayar Üniversitesi Sosyal Bilimler Enstitüsü Yayınlanmamış Yüksek Lisans Tezi.

Gülsevin, G. ve Boz, E. (2004). Eski Anadolu Türkçesi, Ankara: Gazi Kitabevi.

Haim, S. (1953). Farhang Moaser Persian-English Dictionary, Tehran: Farhang Moaser Publishers.

Johnson, F. (1852). Dictionary Persian, Arabic and English, London: W. H. Allen and Co.

Junker, H. \& Bozorg A. (1965). Persisch-Deutcsches Wörterbuch, Tehran: Kamangır Publications.

Köprülü, M. F. (1926). Ferhengnâme-yi Sadî Tercümesi yahut Muhtasar Bostan Tercümesi, Türkiyat Mecmuasi, 2, 481-489.

Logatnâme-yi Dekhoda. Erişim adresi: https://www.parsi.wiki/

Merhan, A. ve Şan, F. (2016). Eski Anadolu Türkçesi Notlar ve Metinler, Ankara: BilgeSu Yayınları.

Moin, M. (1997). Farhang-e Farsi, Tehran: İntişârât- Edina.

Muallim Rifat. (1340-1342 -M.1921-1922-). Ferhengnâme-yi Sadî Tercümesi yahut Muhtasar Bostan Tercümesi, Hoca Mes' 'ūd bin 'Osmān, İstanbul: Âmire Matbaas1.

Menınski, F. (2000). Thesaurus Linguarum Orientalium, Turcicae, Arabicae, Persicae, I-VI, (Yayımlayan: Ölmez, M.), İstanbul: Simurg Yayınları. (İlk yayım M.DC.LXXX:1680)

Olgun, İ. (1973). Farsça ve Türkçe Atasözleri ve Deyimler Üzerine, Türk Dili Araştırmaları YıllığıBelleten, 20, 153-172.

Redhouse, J. W. (1890). Redhouse English-Turkish Dictionary, İstanbul.

Sa'dî-yi Şirazi. (1388 -M.2009-). Bostan, Tehran: Peyman.

Sa'dî-yi Şirazi. (1980). Bostan ve Gülistan, (çeviren: Kilisli Rifat Bilge), 12. bask1, İstanbul: Zafer Matbaası.

Stachowski, S. (1998). Osmanlı Türkçesinde Yeni Farsça Alıntılar Sözlüğ̈̈, Wörterbuch der neupersischen Lehnwörter im Osmanich-Türkischen, (yayımlayan: Ölmez, M.), İstanbul: Simurg Yayınevi.

Steingass, Franz Josef. (1892). Comprehensive Persian-English Dictionary, 8, London-New York. 
Şan, F. (2013). Ferhengnâme-yi Sa'dî Tercümesi’nin Kopenhag Nüshası Hakkında İlk Değerlendirme, Türk Dilleri Araştırmaları, 23 (2), 203-222.

Tarama Sözlüğü, (1963-1977) .I-VIII, Ankara: Türk Dil Kurumu.

Tietze, A. (1999). Wörterbuch der griechischen, slavischen, arabischen und persischen Lehnwörter im Anatolischen Türkish [Anadolu Türkçesindeki Yunanca, İslavca, Arapça ve Farsça Ödünçlemeler Sözlü̈̆̈̈], (Derleyen: Ölmez, M.), İstanbul: Simurg Yayınları.

Zenker, J. T. (1866-1867). Türkisch-arabisch-persisches Handwörterbuch, Leipzig: Strauss \& Cramer GmbH. 